\title{
Scalp reconstructive flaps
}

\author{
Craig Cameron Brawley, Douglas Sidle \\ Department of Otolaryngology-Head and Neck Surgery, Northwestern University Feinberg School of Medicine, Chicago, IL \\ 60611, USA. \\ Correspondence to: Dr. Craig Cameron Brawley, Department of Otolaryngology-Head and Neck Surgery, Northwestern \\ University Feinberg School of Medicine, 675 N Saint Clair St, Fifteenth Floor, Suite 200, Chicago, IL 60611, USA. \\ E-mail: craig.brawley@northwestern.edu
}

How to cite this article: Brawley CC, Sidle D. Scalp reconstructive flaps. Plast Aesthet Res 2022;9:6.

https://dx.doi.org/10.20517/2347-9264.2021.107

Received: 26 Sep 2021 First Decision: 8 Nov 2021 Revised: 9 Nov 2021 Accepted: 14 Dec 2021 Published: 14 Jan 2022

Academic Editors: Matthew Spector, Mark K. Wax Copy Editor: Xi-Jun Chen Production Editor: Xi-Jun Chen

\begin{abstract}
Scalp reconstruction requires keen insight into underlying anatomy and surgical armamentarium. The reconstructive surgeon must consider a plethora of complexities to devise a safe and cosmetically maximized outcome. The purpose of this article is to review scalp reconstruction techniques and the current literature in the framework of the reconstructive ladder, with special emphasis on local flap consideration, design, and execution.
\end{abstract}

Keywords: Scalp reconstruction, scalp defects, local flaps, scalp flaps, reconstructive ladder

\section{INTRODUCTION: SCALP COMPLEXITIES AND THE RECONSTRUCTIVE LADDER}

There are many aspects of the scalp which make reconstruction difficult. The contour of the skull is primarily convex but variable per region and patient. Although highly vascular, the layers of the scalp are thick with an inelastic galea aponeurosis, limiting closure in certain areas. Additionally, the desire to save the hair-bearing scalp and maintain the integrity of a patient's hairline poses a unique cosmetic challenge.

Those challenges and others (i.e., the size of the defect, intact structures, history of radiation, etc.) have propelled many to propose algorithms on how to approach scalp defects ${ }^{[1-8]}$. While it is logical to have a template of the many options available and a decision tree for complicating factors, a more realistic approach involves the application of a reconstructive ladder [Figure 1]. Each step of the ladder represents 


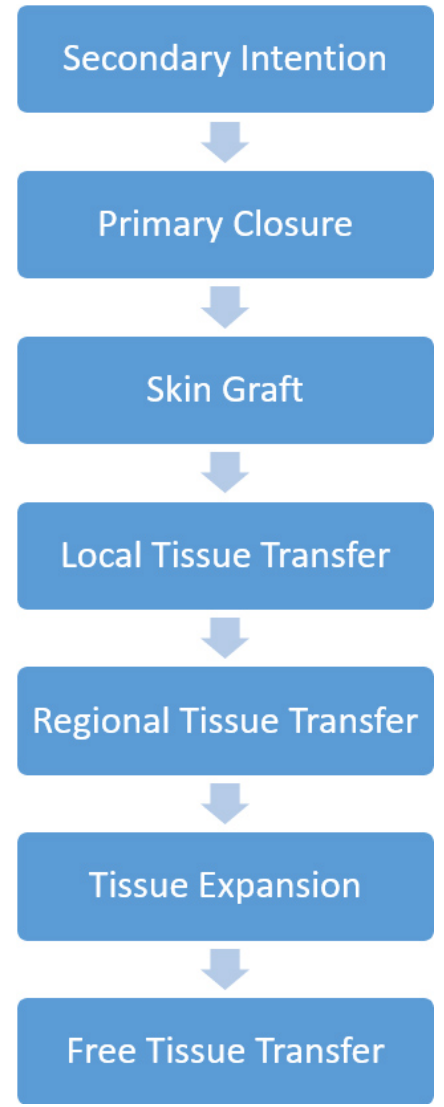

Figure 1. The reconstructive ladder algorithm representing increasing complexity with each additional step.

the increasing complexity of repair ${ }^{[0]}$. Therefore, when approaching reconstruction, the safest, then simplest, then most aesthetically pleasing option should be chosen dependent on each patient.

\section{BRIEF ANATOMIC OVERVIEW}

The skin has the greatest thickness on the scalp, ranging from $3 \mathrm{~mm}$ to $8 \mathrm{~mm}$. The layers of the scalp listed from superficial to deep include the skin, subcutaneous tissue, the galea, loose areolar tissue, and periosteum. The complexity increases for the temporal scalp with the addition of the temporalis muscle and accompanying deep and superficial temporalis fascia. The galea gives the scalp its inelastic properties, and Raposio et al. ${ }^{[10]}$ found that full-thickness galeotomies $1 \mathrm{~cm}$ apart gave an average of $1.67 \mathrm{~mm}$ of extra flap length per galeotomy. Careful attention must be given while performing linear galeotomies as the vascularity of the flap lies in the layer just beyond where the galea is being incised.

The arterial supply of the scalp from an anterior to posterior orientation includes the supratrochlear artery, supraorbital artery, the anterior and posterior branches of the superficial temporal artery, the posterior auricular artery, and the occipital artery [Figure 2]. The frontalis muscle is innervated by the frontal branch of the facial nerve, the occipitalis by the posterior auricular branch of the facial nerve, and the temporalis by the anterior division of the mandibular nerve (V3). Sensation of the scalp is supplied by terminal branches of the trigeminal nerves, as well as the greater and lesser occipital nerves. 

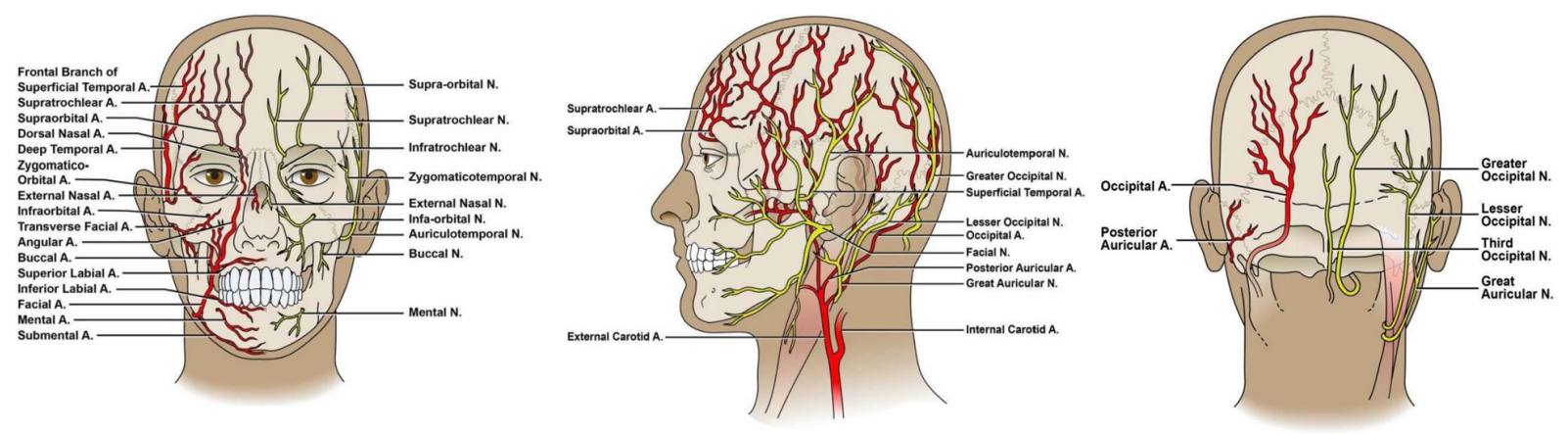

Figure 2. Innervation and arterial supply of the scalp and head.

\section{SECONDARY INTENTION}

Secondary intention is the first option when approaching the reconstructive ladder. This pertains to granulation and healing of the defect without attempting to close the tissue and skin with sutures. In patients who are not surgical candidates or have multiple defects, the potential final result of this method should not be discounted, even in terms of cosmesis [Figure 3]. Ideal conditions include lighter skin color, baseline alopecia, and a maintained periosteum; however, several studies have shown that secondary intention is possible yet delayed with an absent periosteum ${ }^{[1,12]}$. Prolonged wound healing time is an obvious disadvantage to secondary intention, with others including skin mismatch, telangiectasias, alopecia, and the risk of osteomyelitis.

Wound vacuum-assisted closure (VAC) has been used in exposed scalp wounds in several case reports, attesting that wound VACs can accelerate granulation via promoting vascularization, debriding dead tissue, removing excess fluid, and decreasing bacterial colonization ${ }^{[13-15]}$. These findings have been corroborated by a recent meta-analysis and systematic review pertaining to wound VACs $v s$. standard wound therapy in all parts of the body ${ }^{[16]}$.

\section{PRIMARY CLOSURE}

Primary wound closure should be considered for small defects. Most defects with a diameter less than $3 \mathrm{~cm}$ on the scalp can be closed after wide undermining of the surrounding tissue in the subgaleal plane ${ }^{[17]}$. Wound tension on the hair-bearing scalp can lead to alopecia. Closure tension should be placed on the galea since it is the most inelastic layer and is deep to hair follicles ${ }^{[17]}$. As with all defects undergoing primary closure, a fusiform design with a 1:3 width to length ratio between the short and long axis is ideal ${ }^{[18]}$. Standing cutaneous deformities resolve over time generally and can be camouflaged in the hair-bearing scalp.

\section{SKIN GRAFTING AND BIOMATERIAL}

Split- or full-thickness skin grafting are reliable options in the setting of an intact periosteum or granulation tissue supplied by a vascular bed. Full-thickness grafts can be harvested from the skin overlying level V cervical lymph nodes depending on skin laxity and redundancy. A dermatome is required for split-thickness grafts, which are usually harvested from the anterior thigh. A recent case series of over 100 patients noted no significant difference in graft adherence or complications between the two graft options on the scalp ${ }^{[19]}$. A bolster, which is typically cotton wrapped in petroleum gauze and sutured to surrounding tissue to apply pressure to the graft, or a wound VAC is required for approximately one week to allow for plasmatic imbibition, inosculation, and revascularization. 


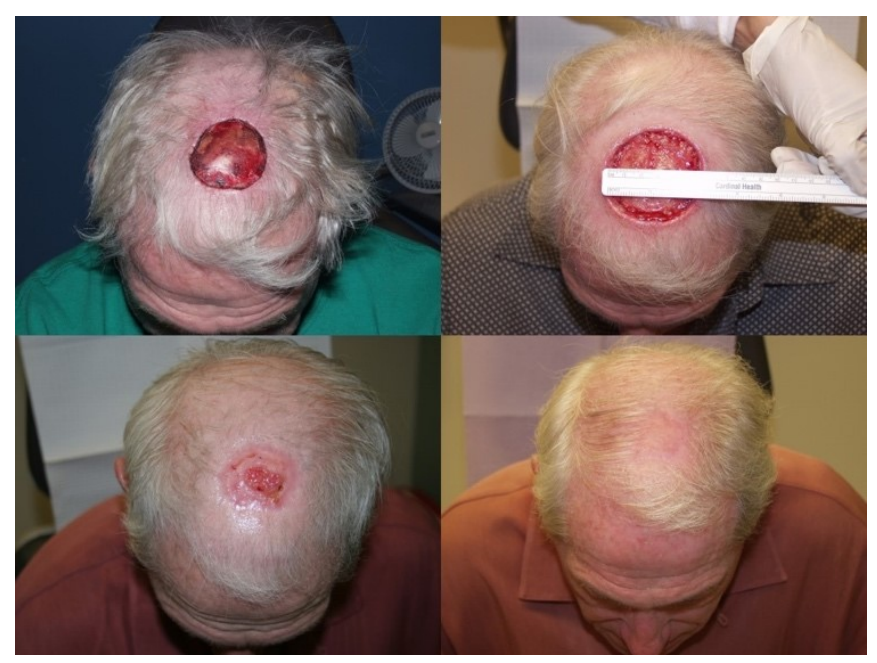

Figure 3. Secondary intention over the course of 7 months.

In scenarios of very large full-thickness scalp defects, the crane principle can be used prior to skin grafting. This technique involves temporary locoregional flap coverage of a defect, with the return of the flap to its original location after at least one week, allowing for appropriate granulation of the defect before additional grafting ${ }^{[20]}$. It was first described for the scalp by Figi and Struthers ${ }^{[21]}$ in 1955 , then the term was coined by Millard $^{[22]}$ in 1969 for an abdominal flap in hand reconstruction, stating "a pedicle flap can be used as an engineering crane to lift and transport subcutaneous tissue from one area and deposit it to another".

Biomaterials should be considered in cases with absent periosteum or a compromised vascular bed. Integra (Integra LifeSciences) is a dermal regeneration template composed of a superficial silicone layer and a deep composite layer. This composite layer is comprised of bovine type I collagen and shark chondroitin- 6 sulfate glycosaminoglycan ${ }^{[23]}$. After 3-6 weeks on the scalp bed, appropriate host cell integration of the biomatrix will have occurred, and the silicone layer is removed ${ }^{[24]}$. It is then replaced with a split-thickness skin graft. A systematic review of success rates on the scalp favors the fenestration of Integra ${ }^{[25]}$.

\section{LOCAL AND REGIONAL FLAPS}

Replacing excised tissue with similar tissue is a key pillar for optimizing results aesthetically. Unfortunately, there is no donor site that can replicate the thickness, biomechanics, and hair-bearing nature of the scalp. This makes local and regional flaps the ideal choice for replacing small to large scalp defects when possible.

Contraindications to local flap closures include scarcity of tissue for appropriate closure, uncleared malignancy, and other relative factors which may lead to poor wound healing, such as smoking, anticoagulation, and prior radiation ${ }^{[26,27]}$. Irradiated tissue is associated with slow wound healing, flap necrosis, wound dehiscence and increased local infection rates ${ }^{[28-30]}$. Rhomboid flaps have been reported to be a successful choice in head and neck reconstruction of irradiated tissue ${ }^{[28]}$. Preoperative assessment of defect size and the ability of the surgeon to create a tension-free closure is pivotal when considering locoregional flaps in previously radiated tissue ${ }^{[31]}$. If this is not feasible, free tissue transfer of healthy, nonradiated tissue should be favored. Advanced age of patients may be beneficial for tissue and skin laxity aiding in the success of local flaps; however, nutritional status should be evaluated regarding poor wound healing. Common complications of locoregional flaps include dehiscence, necrosis, hematoma, infection, pain, alopecia, and poor cosmetic outcomes resulting in subsequent surgeries. Newman et al. ${ }^{[3]}$ reported 
overall complication rates of local flaps at $24.1 \%$ in their retrospective review of scalp defects. On review of the literature, there is no high-powered study that documents each specific complication and associated rates for local flaps.

When approaching scalp defects with locoregional flaps as a reconstructive option, decision making is dependent on the defect size and location. These factors can narrow the choices, with the understanding that other reconstructive options may also be successful. Therefore, the proceeding sections will begin with a picture of a defect to initiate the reconstructive thought process for the reader.

\section{Vertex scalp defects}

The vertex is the most inelastic portion of the scalp due to the confluence of the galea without an accompanying muscle layer [Figure 4]. Due to the biomechanics, increased undermining must be performed for either primary or local flap closure. Small defects under $2-3 \mathrm{~cm}$ in diameter should be closed primarily.

The triple rhombic flap, also known as a multiple Limberg flap, is a three pedicled transposition flap primarily used to close to medium-sized defects on the vertex of the scalp where laxity is scarce ${ }^{[32,33]}$. Derivatives of this flap include the rotational pinwheel and multiple O-to- $\mathrm{Z}$ flaps. The author has found the triple rhombic flap to be more effective than the derivatives due to better distal flap tip vascularity and less opportunity for central dehiscence. The triple rhombic flap is designed to close an approximate hexagonal $\operatorname{defect}^{[32]}$. Perpendicular lines are drawn from 3 equidistant locations around the defect, extending away from the defect to a length of approximately of one side of the hexagon. Once that length has been reached, 60-degree angles are drawn in a clockwise (or counterclockwise) fashion using this same distance. After scalp undermining and incisions, the flaps are rotated in the same direction to fill the defect [Figure 5].

Closure of larger defects up to $72 \mathrm{~cm}^{2}$ have been reported with modified quadruple rhombic flaps ${ }^{[34]}$. A benefit of multiple rhombic flaps in this location is that rotating tissue into itself will recreate the natural "whorl" hair pattern seen at the vertex by recruiting tissue 360 degrees around the defect ${ }^{[2]}$. This pattern can also be recreated with a spiral rotational flap; however, this is more suitable for smaller defects ${ }^{[35]}$. Additionally, should a patient already have alopecia at the vertex, the triple rhombic flap has been successfully used for the sole purpose of cosmesis and hair restoration ${ }^{[36]}$. Because of the central design of this flap and the apical nature of the vertex itself, its high success rate and versatility with all defect sizes, the triple rhombic flap should be highly considered for any solitary vertex defect in a non-radiated scalp.

Other flap choices for larger defects of the vertex include double opposing rotational flaps with or without skin graft supplementation centrally. Still larger defects may require free flap coverage or tissue expansion.

\section{Anterior scalp and forehead defects}

Due to this cosmetically sensitive location, extensive communication with the patient should occur regarding reconstructive expectations [Figure 6]. Smaller defects under 1-2 cm in diameter can be closed primarily with appropriate undermining. The hairline and brow position must always be considered preoperatively. More extensive undermining should be performed posteriorly as not to disrupt these structures.

Double opposing rectangular advancement flaps, also known as $\mathrm{H}$-flaps, can be used for anterior scalp and forehead defects greater than $2 \mathrm{~cm}$. A major advantage of this flap is that the incisions are parallel and can camouflage with resting skin tension lines of the forehead. Its parallel orientation also optimizes brow and 


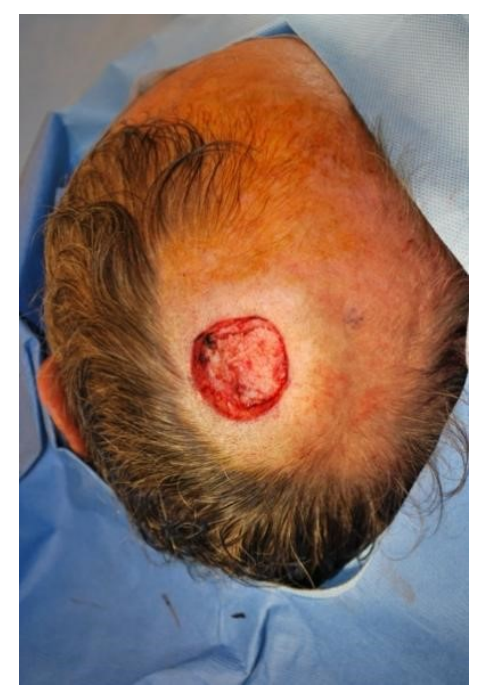

Figure 4. Defect of the vertex scalp

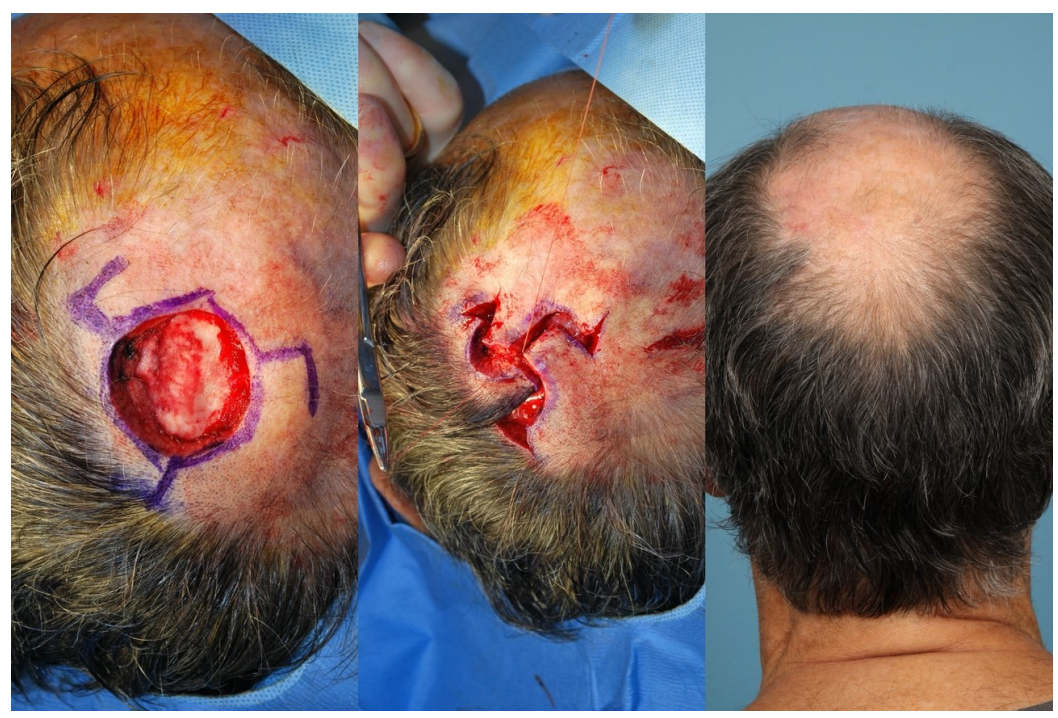

Figure 5. Vertex scalp defect closed with a triple rhombic flap.

frontal hairline symmetry [Figure 7]. This flap has a length-to-width ratio of 2:1 and has been shown to adequately cover defects up to $6 \mathrm{~cm}$ in diameter ${ }^{[37]}$. Bilateral excisions of Burrow's triangles are required for the best cosmetic outcomes.

Other local flap considerations include V-Y flaps, bilobed flaps, and rotational advancement flaps for medium-sized defects. Again, due to the brow and hairline, skin laxity and vector appropriate undermining should be considered before flap execution.

The temporo-parietal-occipital flap, also known as the Juri flap, is a large monopedicled flap used to repair anterior scalp defects, deriving its vascular supply from the posterior (or sometimes anterior) branch of the superficial temporal artery ${ }^{[38]}$. This can be considered for anterior scalp defects greater than $20 \mathrm{~cm}^{2}$. Generally, the majority of the donor site is in the parietal scalp, which has the most tissue laxity due to the 


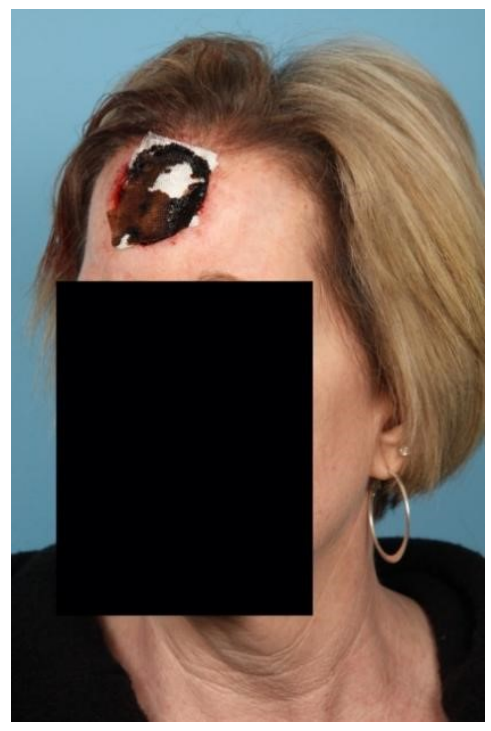

Figure 6. Defect of the anterior scalp and forehead.

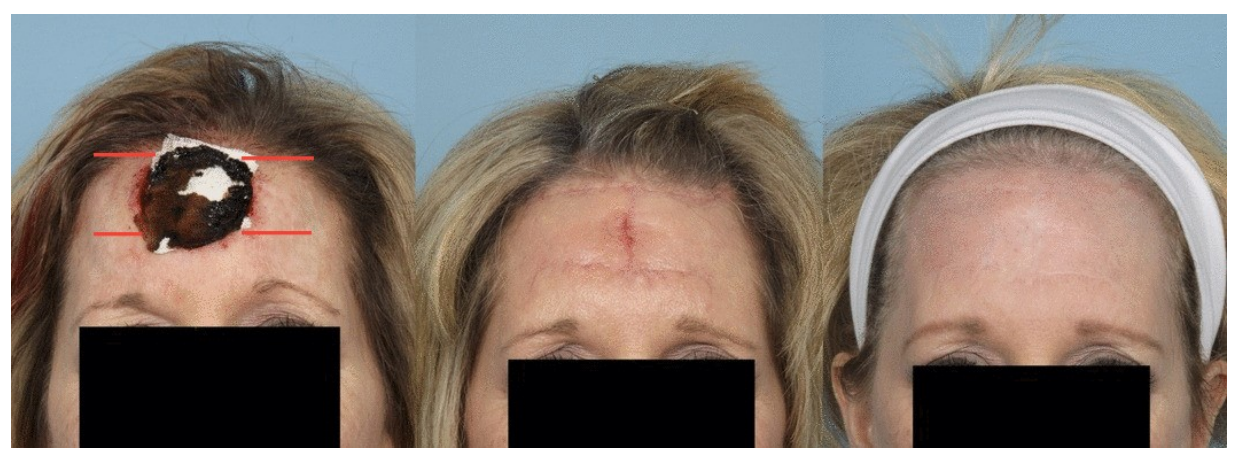

Figure 7. H-flap used for a large, midline anterior scalp/forehead defect. Scarring reflected natural resting skin tension lines, and eyebrow symmetry was not distorted (note: digital presurgical markings were added to the leftmost picture).

temporoparietal fascia overlying the deep temporal fascia. The dimensions of the flap can reach up to 4 to $5 \mathrm{~cm}$ in width and 24 to $26 \mathrm{~cm}$ in length ${ }^{[39]}$. Careful surgical planning with arterial tracing via doppler and palpation is recommended. The Juri flap has the advantage of a robust vasculature and hair-bearing tissue transfer. It can also be used for free tissue transfer ${ }^{[40]}$.

\section{Occipital scalp defects}

Defects and repairs of the occiput have the advantage of easier camouflage with long hair [Figure 8]. In addition, patients are less cosmetically sensitive to this area since it is not routinely visualized by them. The occipital scalp has moderate skin laxity with the advantage of posterior cervical tissue for advancement purposes. Defects ranging from $2-4 \mathrm{~cm}$ in diameter can be closed primarily with circumferential undermining.

Posterior cervical rotation flaps are the workhorse for medium-sized occipital scalp defects. Due to the contour of the scalp, longer incisions for rotational flaps may be needed, with some literature citing a length up to 6 times the greatest diameter of the defect ${ }^{[1,42]}$. The anterior cervical rotation flap has been used to repair midface defects due to its high success rate and excellent color and texture match ${ }^{[43]}$. Similarly, we 


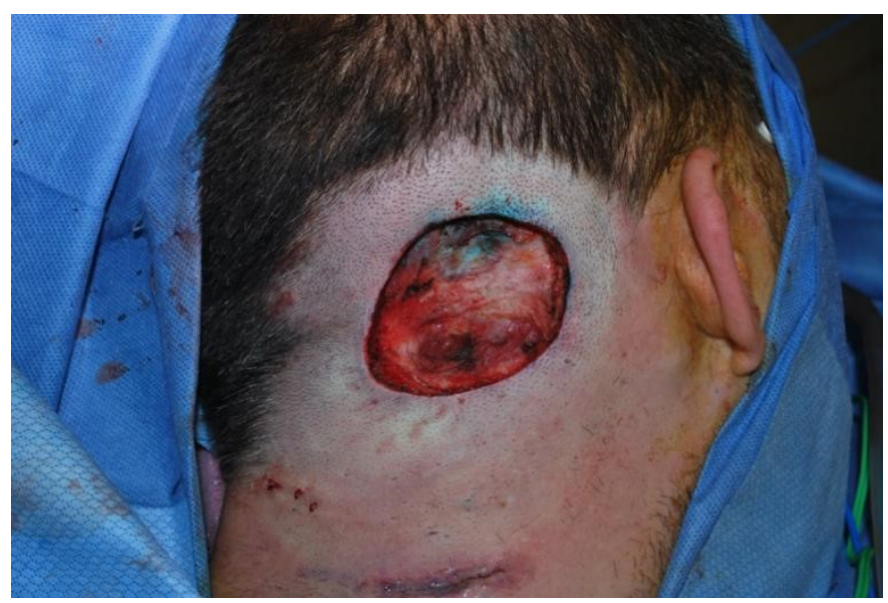

Figure 8. Defect of the occipital scalp (note: this image has been slightly altered to remove presurgical markings).

have found the posterior cervical rotation flap to have a high success rate, color/texture match, versatility, and hairline optimization for occipital scalp lesions [Figure 9].

For larger defects greater than $45 \mathrm{~cm}^{2}$, Orticochea flaps have been described for this location. These flaps require vast undermining for advancement and are pedicled by bilateral superficial temporal arteries and occipital arteries, with a three flap technique favored over a four flap technique ${ }^{[44,45}$. Other regional flaps for large tissue defects in this area include the temporo-parietal-occipital (Juri) flap, the trapezius myocutaneous flap, and the latissimus dorsi myocutaneous flap. The latter two have generally fallen out of favor due to their non-hair-bearing nature and restriction by pedicle length, especially in the era of free flaps; however, reliable results have been reported ${ }^{[46-49]}$.

\section{Temporoparietal scalp defects}

As previously discussed, the temporoparietal scalp is the most mobile portion of the scalp with the addition of the temporoparietal fascia, making local tissue transfer an excellent choice for reconstruction [Figure 10]. However, due to the patient's hairline and proximity of the pinna, careful selection of local flap is needed. Defects ranging from $2-4 \mathrm{~cm}$ in diameter can be closed primarily with undermining and consideration of these structures.

The O-to-Z flap is a double rotation flap used to close a circular defect. The two opposing curvilinear pedicles are rotated toward each other, filling the defect and creating a " $Z$ " shaped suture line. Buckingham et al. ${ }^{[50]}$, based on their cadaveric research, proposed that to achieve minimal suture tension, the lengths of each curvilinear incision should be 4 radii of the defect, with successive polar angles of 45 degrees at 2, 3, and 5 radii from the center of the defect. However, these ideal lengths can be modified with surrounding tissue availability and laxity.

This flap can readily be used on the temporoparietal scalp, with flap design accounting for hair-bearing areas. Camouflage with adjacent hair can be used subsequently [Figure 11]. In larger defects or areas with less skin laxity, a skin graft can supplement the central portion after partial rotations of the flaps are achieved [Figure 12]. 


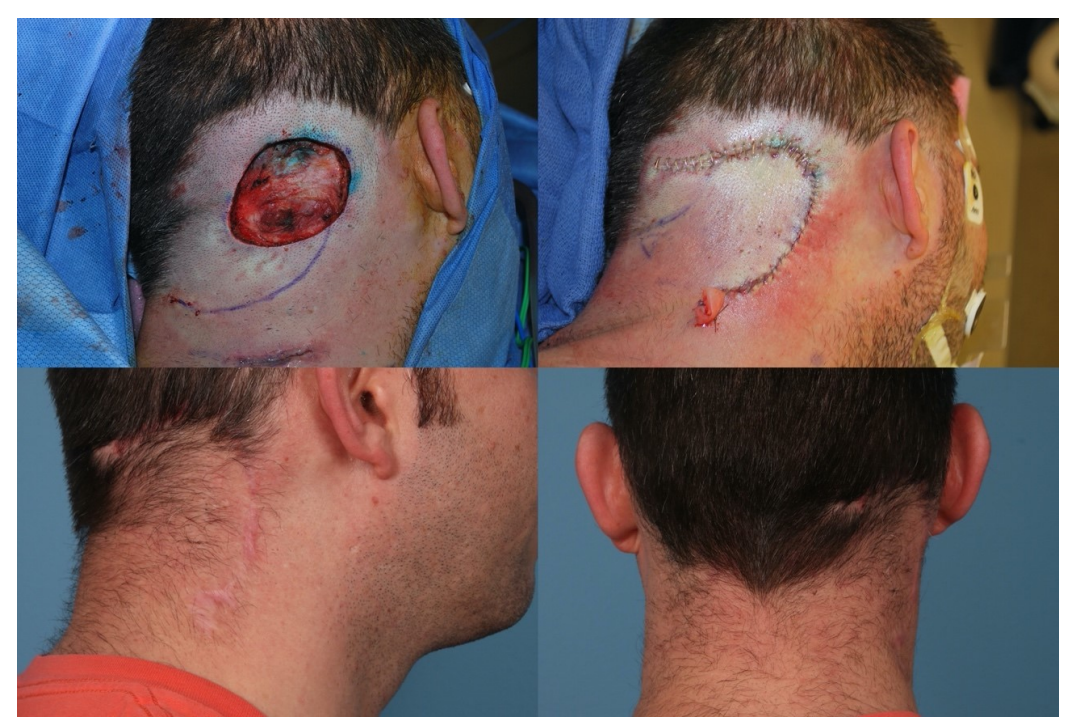

Figure 9. Posterior cervical rotation flap with flap limb designed along the hairline.

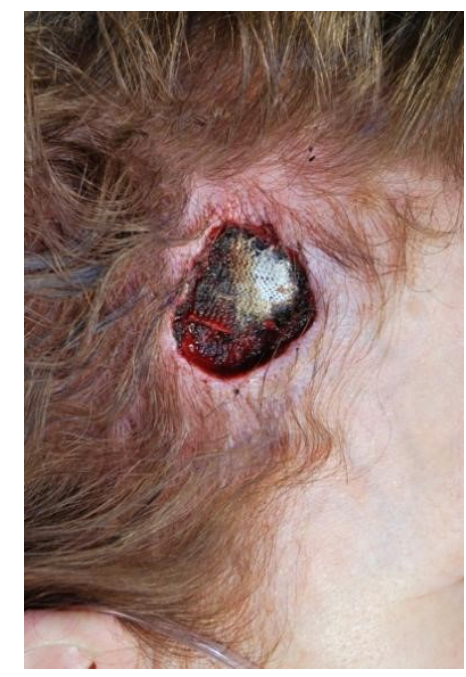

Figure 10. Defects of the temporoparietal scalp (note: these images have been slightly altered to remove presurgical markings).

Other suitable options for medium-sized defects up to $25 \mathrm{~cm}^{2}$ in this area include V-Y flaps, rhomboid flaps, and bilobed flaps. For larger defects, tissue expansion will yield the best cosmetic outcomes ${ }^{[51]}$.

\section{TISSUE EXPANDERS}

In larger defects where hairline distortion is likely with local flaps, a tissue expander should be considered. This is a staged operation that requires thorough patient communication and reliability, with an understanding that unsightly tissue expansion in the short term may give rise to the patient's best ultimate cosmetic outcome [Figure 13]. Close follow-up and risk/benefit counseling should be discussed with each patient.

Tissue expanders have been reported to cover a 50\% scalp defect adequately ${ }^{[52]}$. Expanders are placed in the subgaleal plane through a small incision at a perpendicular orientation. The expansion process is recommended to begin between 7 and 14 days after implantation, as the galea loses its rigid, inelastic 


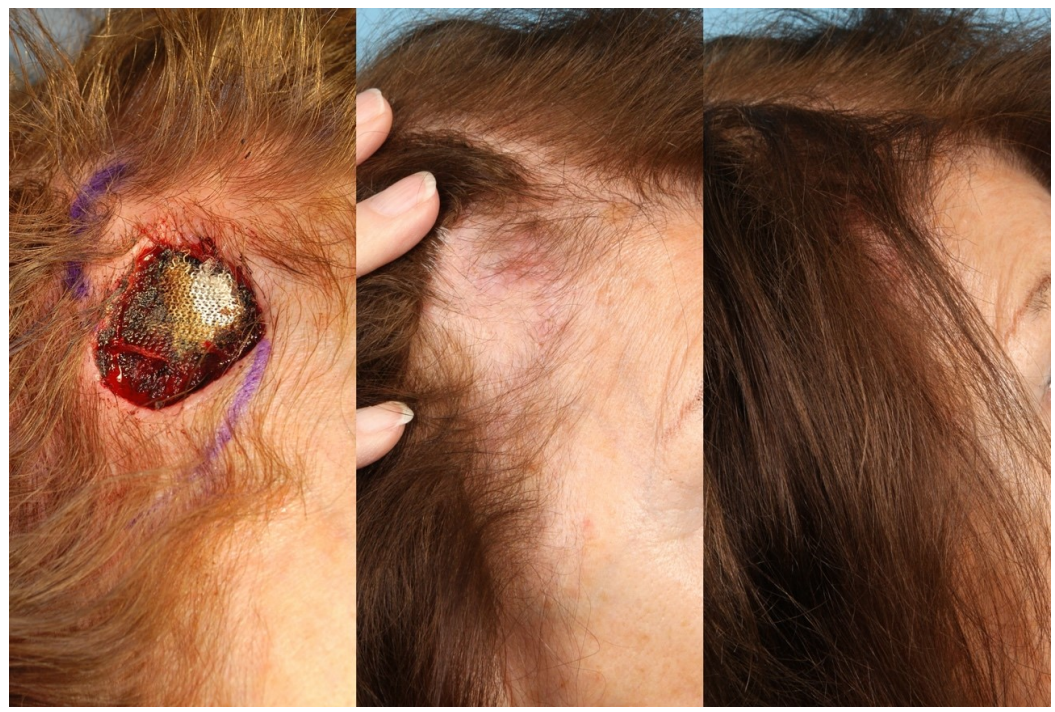

Figure 11. O-to-Z local flap in the temporal region. Flap limbs were designed with respect to the hairline, and additional camouflage can be used after healing is complete.

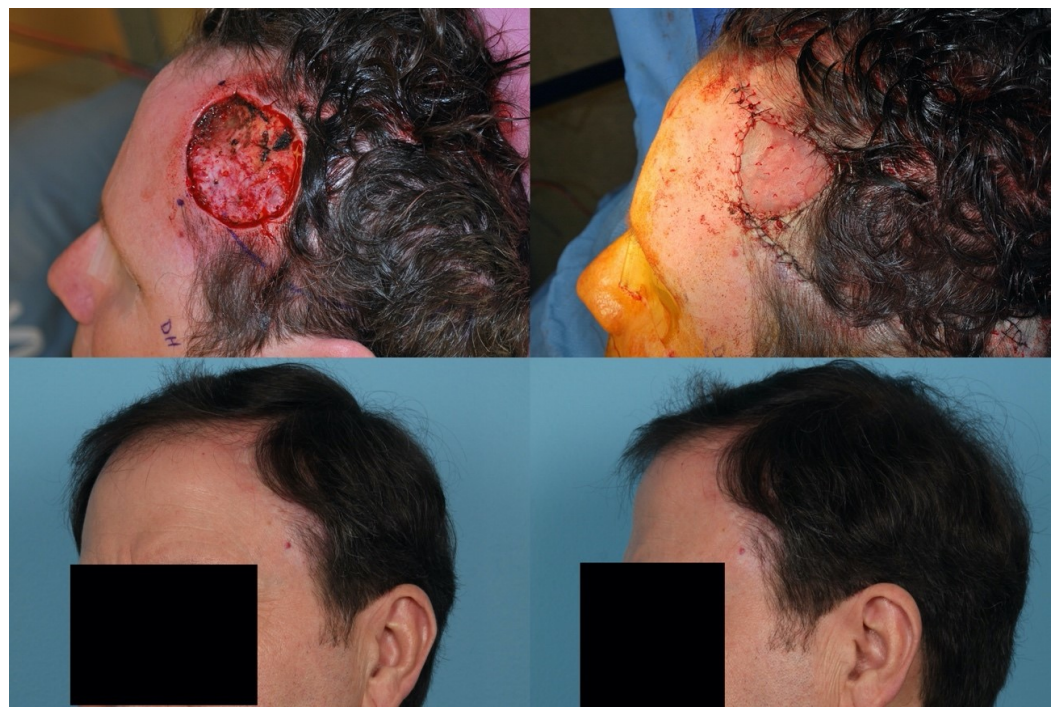

Figure 12. O-to-Z local flap in the temporal region with centrally located split-thickness skin graft for closure of the defect. This demonstrates that the best aesthetic result may be achieved by a combination of techniques, mitigating the notion that complete flap closure must be achieved.

structure after approximately 11 days ${ }^{[5,5,5]}$. Expansion intervals should be approximately every 5-7 days for the scalp, and while additive volumes vary, they are generally around $10 \%$ of the volume goal for each session $^{[3,54]}$. Desired expansion duration can take weeks to months based on surgeon preference. Rectangular base expanders are reported to give the largest tissue gains ${ }^{[55]}$. Several methods have been proposed in choosing the size of the expander based on the size of the defect for adequate coverage. These formulas vary from selecting an expander with a base twice the size of the defect ${ }^{[53]}$ to more complex algorithms ${ }^{[56]}$. Others have simply proposed using the largest expander possible to minimize tissue recoil and eventual closure tension ${ }^{[57]}$. 


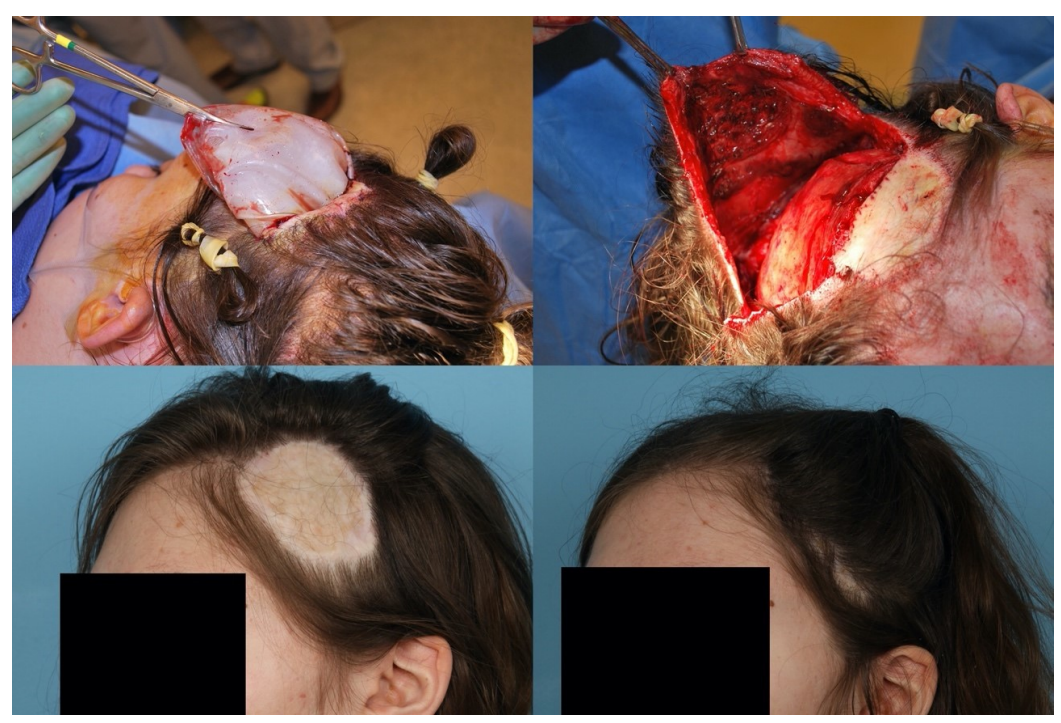

Figure 13. Temporal scalp defect closed with a skin graft from another surgeon, resulting in an unacceptable cosmetic outcome. A tissue expander was placed posteriorly in the parieto-occipital scalp. Starting on post-operative day ten, $20 \mathrm{~mL}$ injections of saline were initiated, with six additional $20 \mathrm{~mL}$ injections at 5-day intervals. After one month, the tissue expander was removed, the skin graft was excised, and the defect was closed with excellent cosmesis.

The complications of tissue expansion are well described in the literature ${ }^{[57]}$. Complication rates are $15 \%$ $20 \%$, with failures estimated around $6 \%{ }^{[54]}$.

\section{FREE FLAPS}

For large and complex defects, free tissue transfer with microvascular anastomosis may be necessary for optimized closure. Cumulative factors favoring this option include large defects, irradiation, scalp inelasticity, unfavorable location, chronic wound infection, cranial defect, prior cranioplasty, and/or exposed implanted structures ${ }^{[58]}$.

Flap selection should be dependent on the size of the defect, composite material, aesthetic contour, and surgeon's comfort. According to a 2015 pooled analysis of the literature, the most commonly used free flap on the scalp is the latissimus dorsi flap, with the anterolateral thigh flaps as the second most common ${ }^{[59]}$. Another study noted that the anterolateral thigh flap has been the most commonly reported scalp flap since 2000 , inferring increasing popularity ${ }^{[00]}$. Although advanced age has not been shown to increase mortality or complications, patient condition and goals regarding other comorbidities should be discussed and considered $^{[5,6,1]}$.

\section{CONCLUSION}

Scalp reconstruction should be approached via the reconstructive ladder, with special consideration to safety, success probability, and aesthetic optimization. Choosing the best method of reconstruction is dependent on scalp complexities, defect size, location, tissue viability, hairline distortion, and surgeon expertise. The key cosmetic tenet of replacing "like with like" makes local flaps a preferred option when plausible.

\section{DECLARATIONS}

\section{Authors' contributions}

Made substantial contributions to conception and design of the study and performed literature review and 
interpretation: Brawley CC, Sidle D

\section{Availability of data and materials}

Not applicable.

\section{Financial support and sponsorship}

None.

\section{Conflicts of interest}

Both authors declared that there are no conflicts of interest.

\section{Ethical approval and consent to participate}

Not applicable.

\section{Consent for publication}

A written informed consent was obtained from all patients. Dr. Sidle obtained the copyright of Figure 2.

\section{Copyright}

(c) The Author(s) 2022.

\section{REFERENCES}

1. Desai SC, Sand JP, Sharon JD, Branham G, Nussenbaum B. Scalp reconstruction: an algorithmic approach and systematic review. JAMA Facial Plast Surg 2015;17:56-66. DOI PubMed

2. Leedy JE, Janis JE, Rohrich RJ. Reconstruction of acquired scalp defects: an algorithmic approach. Plast Reconstr Surg 2005;116:54e72e. DOI PubMed

3. Newman MI, Hanasono MM, Disa JJ, Cordeiro PG, Mehrara BJ. Scalp reconstruction: a 15-year experience. Ann Plast Surg 2004;52:501-6; discussion 506. DOI PubMed

4. Iblher N, Ziegler MC, Penna V, Eisenhardt SU, Stark GB, Bannasch H. An algorithm for oncologic scalp reconstruction. Plast Reconstr Surg 2010;126:450-9. DOI PubMed

5. Janus JR, Peck BW, Tombers NM, Price DL, Moore EJ. Complications after oncologic scalp reconstruction: a 139-patient series and treatment algorithm. Laryngoscope 2015;125:582-8. DOI PubMed

6. Zhou Y, Jiang Z, Li C, et al. An algorithm for one-stage malignant oncologic scalp reconstruction. Ann Transl Med 2020;8:432. DOI PubMed PMC

7. Harirah M, Sanniec K, Yates T, Harirah O, Thornton JF. Scalp reconstruction after mohs cancer excision: lessons learned from more than 900 consecutive cases. Plast Reconstr Surg 2021;147:1165-75. DOI PubMed

8. Temple CL, Ross DC. Scalp and forehead reconstruction. Clin Plast Surg 2005;32:377-90, vi. DOI PubMed

9. Simman R. Wound closure and the reconstructive ladder in plastic surgery. J Am Col Certif Wound Spec 2009;1:6-11. DOI PubMed PMC

10. Raposio E, Santi P, Nordström RE. Effects of galeotomies on scalp flaps. Ann Plast Surg 1998;41:17-21. DOI PubMed

11. Becker GD, Adams LA, Levin BC. Secondary intention healing of exposed scalp and forehead bone after Mohs surgery. Otolaryngol Head Neck Surg 1999;121:751-4. DOI PubMed

12. Snow SN, Stiff MA, Bullen R, Mohs FE, Chao W. Second-intention healing of exposed facial-scalp bone after Mohs surgery for skin cancer: Review of ninety-one cases. J Am Acad Dermatol 1994;31:450-4. DOI PubMed

13. Ahmed O, Storey CM, Zhang S, Chelly MR, Yeoh MS, Nanda A. Vacuum-assisted closure of necrotic and infected cranial wound with loss of dura mater: a technical note. Surg Neurol Int 2015;6:11. DOI PubMed PMC

14. Marathe US, Sniezek JC. Use of the vacuum-assisted closure device in enhancing closure of a massive skull defect. Laryngoscope 2004;114:961-4. DOI PubMed

15. Subotic U, Kluwe W, Oesch V. Community-associated methicillin-resistant Staphylococcus aureus-infected chronic scalp wound with exposed dura in a 10-year-old boy: vacuum-assisted closure is a feasible option: case report. Neurosurgery 2011;68:E1481-3; discussion E1484. DOI PubMed

16. Zens Y, Barth M, Bucher HC, et al. Negative pressure wound therapy in patients with wounds healing by secondary intention: a systematic review and meta-analysis of randomised controlled trials. Syst Rev 2020;9:238. DOI PubMed PMC

17. Baker SR. Local flaps in facial reconstruction. 3rd ed. Philadelphia, PA: Elsevier/Saunders; 2014. p. 643.

18. Goldberg LH, Alam M. Elliptical excisions: variations and the eccentric parallelogram. Arch Dermatol 2004;140:176-80. DOI PubMed 
19. Hilton CMH, Hölmich LR. Full- or split-thickness skin grafting in scalp surgery? World J Plast Surg 2019;8:331-7. DOI PubMed PMC

20. Lu Y, Chang KC, Chang CN, Chang DH. Reconstruction of a secondary scalp defect using the crane principle and a split-thickness skin graft. BMC Surg 2021;21:41. DOI PubMed PMC

21. Figi A, Struthers AH. The treatment of skalp deformities. Coll Papers Mayo Clin 1955;47:375. DOI

22. Millard DR. The crane principle for the transport of subcutaneous tissue. Plast Reconstr Surg 1969;43:451-62. DOI PubMed

23. Yan S, Shi H, Chen D, Guo J, Sun Y, Wu S. Repair of large full-thickness scalp defects using biomaterial and skin grafting. $J$ Craniofac Surg 2018;29:e426-9. DOI PubMed

24. Moiemen NS, Staiano JJ, Ojeh NO, Thway Y, Frame JD. Reconstructive surgery with a dermal regeneration template: clinical and histologic study. Plast Reconstr Surg 2001;108:93-103. DOI PubMed

25. Johnson MB, Wong AK. Integra-based reconstruction of large scalp wounds: a case report and systematic review of the literature. Plast Reconstr Surg Glob Open 2016;4:e1074. DOI PubMed PMC

26. Kinsella JB, Rassekh CH, Wassmuth ZD, Hokanson JA, Calhoun KH. Smoking increases facial skin flap complications. Ann Otol Rhinol Laryngol 1999;108:139-42. DOI PubMed

27. Lewis KG, Dufresne RG Jr. A meta-analysis of complications attributed to anticoagulation among patients following cutaneous surgery. Dermatol Surg 2008;34:160-4; discussion 164-5. DOI PubMed

28. Kurul S, Dinçer M, Kizir A, Uzunismail A, Darendeliler E. Plastic surgery in irradiated areas: analysis of 200 consecutive cases. Eur J Surg Oncol 1997;23:48-53. DOI PubMed

29. Miller SH, Rudolph R. Healing in the irradiated wound. Clin Plast Surg 1990;17:503-8. PubMed

30. Horn DB, Adams GL, Monyak D. Irradiated soft tissue and its management. otolaryngologic clinics of North America 1995;28:100319. PubMed

31. Entezami P, Aminpour S. Revisiting closure options for heavily irradiated tissue following Mohs excision: a case report and review of literature. Ann Med Surg (Lond) 2015;4:44-7. DOI PubMed PMC

32. Turan T, Kuran I, Ozcan H, Baş L. Geometric limit of multiple local Limberg flaps: a flap design. Plast Reconstr Surg 1999;104:16758. DOI PubMed

33. Limberg AA. Design of local flaps. Mod Trends Plast Surg 1966;2:38-61. PubMed

34. Varnalidis I, Mantelakis A, Spiers HVM, Papadopoulou AN. Application of the pinwheel flap for closure of a large defect of the scalp. BMJ Case Rep 2019;12:e229420. DOI PubMed PMC

35. Mastacouris NC, Scott AR. The spiral flap: a novel approach to scalp closure in children. Am J Otolaryngol 2021;42:102852. DOI PubMed

36. Stough DB, Stough DB. Triple rhomboid flap for crown alopecia correction. J Dermatol Surg Oncol 1990;16:543-8. DOI PubMed

37. Ebrahimi A, Nejadsarvari N. Upper forehead skin reconstruction with h-flap. J Cutan Aesthet Surg 2013;6:152-4. DOI PubMed PMC

38. Juri J. Use of parieto-occipital flaps in the surgical treatment of baldness. Plast Reconstr Surg 1975;55:456-60. PubMed

39. Juri J, Valotta MF. The use of the Juri temporo-parieto-occipital flap. Semin Plast Surg 2005;19:128-36. DOI

40. Juri J, Juri C. Two new methods for treating baldness: temporo-parieto-occipito-parietal pedicled flap and temporo-parieto-occipital free flap. Ann Plast Surg 1981;6:38-47. DOI PubMed

41. Earnest LM, Byrne PJ. Scalp reconstruction. Facial Plast Surg Clin North Am 2005;13:345-53, vii. DOI PubMed

42. Costa DJ, Walen S, Varvares M, Walker R. Scalp rotation flap for reconstruction of complex soft tissue defects. J Neurol Surg B Skull Base 2016;77:32-7. DOI PubMed PMC

43. Cook TA, Israel JM, Wang TD, Murakami CS, Brownrigg PJ. Cervical rotation flaps for midface resurfacing. Arch Otolaryngol Head Neck Surg 1991;117:77-82. DOI PubMed

44. Orticochea M. Four flap scalp reconstruction technique. Br J Plast Surg 1967;20:159-71. DOI PubMed

45. Orticochea M. New three-flap scalp reconstruction technique. Br J Plast Surg 1971;24:184-8. DOI PubMed

46. Tan KC, Tan BK. Extended lower trapezius island myocutaneous flap: a fasciomyocutaneous flap based on the dorsal scapular artery. Plast Reconstr Surg 2000;105:1758-63. DOI PubMed

47. Horch RE, Stark GB. The contralateral bilobed trapezius myocutaneous flap for closure of large defects of the dorsal neck permitting primary donor site closure. Head Neck 2000;22:513-9. DOI PubMed

48. Har-el G, Bhaya M, Sundaram K. Latissimus dorsi myocutaneous flap for secondary head and neck reconstruction. Am J Otolaryngol 1999;20:287-93. DOI PubMed

49. Tanaka Y, Miki K, Tajima S, Akamatsu J, Tsukazaki Y, Inomoto T. Reconstruction of an extensive scalp defect using the split latissimus dorsi flap in combination with the serratus anterior musculo-osseous flap. Br J Plast Surg 1998;51:250-4. DOI PubMed

50. Buckingham ED, Quinn FB, Calhoun KH. Optimal design of O-to-Z flaps for closure of facial skin defects. Arch Facial Plast Surg 2003;5:92-5. DOI PubMed

51. Mangubat EA. Scalp repair using tissue expanders. Facial Plast Surg Clin North Am 2013;21:487-96. DOI PubMed

52. Manders EK, Graham WP 3rd, Schenden MJ, Davis TS. Skin expansion to eliminate large scalp defects. Ann Plast Surg 1984;12:30512. DOI PubMed

53. Radovan C. Tissue expansion in soft-tissue reconstruction. Plast Reconstr Surg 1984;74:482-92. DOI PubMed

54. Mccauley RL. Tissue expansion reconstruction of the scalp. Semin Plast Surg 2005;19:143-52. DOI

55. Rappard JH, Sonneveld GJ, Borghouts JM. Geometric planning and the shape of the expander. Facial Plast Surg 1988;5:287-90. DOI PubMed 
56. Agrawal K, Agrawal S. Tissue regeneration during tissue expansion and choosing an expander. Indian J Plast Surg 2012;45:7-15. DOI PubMed PMC

57. Manders EK, Schenden MJ, Furrey JA, Hetzler PT, Davis TS, Graham WP 3rd. Soft-tissue expansion: concepts and complications. Plast Reconstr Surg 1984;74:493-507. DOI PubMed

58. Steiner D, Horch RE, Eyüpoglu I, et al. Reconstruction of composite defects of the scalp and neurocranium-a treatment algorithm from local flaps to combined AV loop free flap reconstruction. World J Surg Oncol 2018;16:217. DOI PubMed PMC

59. Sosin M, Schultz BD, De La Cruz C, et al. Microsurgical scalp reconstruction in the elderly: a systematic review and pooled analysis of the current data. Plast Reconstr Surg 2015;135:856-66. DOI PubMed

60. Chang KP, Lai CH, Chang CH, Lin CL, Lai CS, Lin SD. Free flap options for reconstruction of complicated scalp and calvarial defects: report of a series of cases and literature review. Microsurgery 2010;30:13-8. DOI PubMed

61. Sokoya M, Misch E, Vincent A, et al. Free tissue reconstruction of the scalp. Semin Plast Surg 2019;33:67-71. DOI PubMed PMC 